\title{
RHEB methylation in white blood cell, a novel candidate marker for breast cancer screening
}

\author{
Sutasinee Asayut ${ }^{\mathrm{a}, \mathrm{b},+}$, Charoenchai Puttipanyalears ${ }^{\mathrm{c}, \mathrm{d},+}$, Prakasit Rattanatanyong ${ }^{\mathrm{c}, \mathrm{d}}$, \\ Somchai Thanasitthichai ${ }^{\mathrm{e}}$, Nakarin Kitkumthorn ${ }^{\mathrm{f}, *}$, Apiwat Mutirangura ${ }^{\mathrm{c}, \mathrm{d}, *}$ \\ a Program of Medical Science, Faculty of Medicine, Chulalongkorn University, Bangkok 10330 Thailand \\ b Research Division, National Cancer Institute, Bangkok 10400 Thailand \\ c Department of Anatomy, Faculty of Medicine, Chulalongkorn University, Bangkok 10330 Thailand \\ d Center of Excellence in Molecular Genetics of Cancer and Human Diseases, Department of Anatomy, \\ Faculty of Medicine, Chulalongkorn University, Bangkok 10330 Thailand \\ ${ }^{e}$ Institute of Medical Research and Technology Assessment, Department of Medical Services, Ministry of \\ Public Health, Nonthaburi 11000 Thailand \\ f Department of Oral Biology, Faculty of Dentistry, Mahidol University, Bangkok 10400 Thailand
}

*Corresponding authors, e-mail: mapiwat@chula.ac.th, nakarinkit@gmail.com, ${ }^{+}$S. A. and C. P. are co-first authors

Received 22 Oct 2020

Accepted 11 Dec 2020

\begin{abstract}
Aberrant DNA methylation of tumor surrounding stromal cells is one of epigenetic changes, partly caused by the secretion of tumor cells. Here, we searched the tumor-induced DNA methylation profile in white blood cells (WBCs) caused by the secretion of breast cancer cell, that will be possible marker for breast cancer screening. Using DNA methylation microarray, we identified aberrant DNA methylated genes from co-culture model between healthy controls peripheral blood mononuclear cells (PBMCs) with 3 breast cancer cell lines. From bioinformatics analysis, six methylated CpG sites in 3 validation genes were selected for preliminary test to determine the most effective CpG sites for detection in breast cancer patient WBCs using methylation-specific polymerase chain reaction (MSP). After test, the $\operatorname{cg} 03998173$ of RHEB was selected as a validation gene with the result of $100 \%$ sensitivity and $80 \%$ specificity. Later, this methylation marker determined in the WBCs from 200 breast cancer patients and 200 healthy controls by SYBR green-based real-time MSP (RT-MSP). The RHEB methylation were detected in WBCs from 188 (94\%) breast cancer patients and 59 (29.50\%) healthy controls with high sensitivity of $94 \%$ and specificity of $70.50 \%$ (P-value $<0.0001$ ). In conclusion, tumor-induced DNA methylation in WBCs caused by the secretion of breast cancer cells can be effective tumor marker for breast cancer screening. The RHEB methylation is a new highly sensitive and specific tumor marker from DNA methylation change in white blood cells of breast cancer patient blood. Therefore, the RHEB methylation may be considered as a tumor marker for breast cancer screening.
\end{abstract}

KEYWORDS: breast cancer, WBCs, RHEB methylation, tumor marker, breast cancer screening

\section{INTRODUCTION}

Breast cancer is the most common cancer and the number one cause of death from cancer in women. The incidence of cancer across all countries of the world, including Thailand, from the GLOBOCAN 2018 database produced by the International Cancer Research Organization (IARC) showed that there were 2.1 million new cases of breast cancer accounting for almost a quarter of all female cancer cases worldwide. The global age standardized rate (ASR) of breast cancer incidence was 46.3 per 100000 person-years and the global ASR for breast cancer mortality was 13.0 per 100000 person-years [1]. The female breast cancer ASR incidence in Thailand during 2013-2015 from cancer registry database by National Cancer Institute (NCI, Thailand) was 31.4 per 100000 person-years [2]. The mortality from breast cancers was 4177 persons according to the Public Health Statistics A.D. 2017 [3].

There are three appropriate breast cancer screening methods for Thailand: breast selfexamination (BSE), clinical breast examination (CBE) and examination combined with mammography and ultrasound for more accurate diagnosis [4-6]. Currently, the breast cancer screening with blood biomarker has come into play a role, or 
may replace the old screening methods [6]. Bloodbased biomarkers were an alternative non-invasive strategy for cancer screening. Although none of the currently used blood-based biomarkers are sensitive enough for the early detection of breast cancer, an abundance of significant findings to develop the screening tools using blood-based biomarkers have emerged in recent years [7].

Alteration of the epigenome resulting in differential gene expression without a change in DNA sequence is a common phenomenon in tumorigenesis [7]. Aberrant DNA methylation is an epigenetic change which is partly caused by the secretion of tumor cells to surrounding stromal cells. In a previous study, LINE-1 hypermethylation in micrometastatic lymph nodes and surrounding cells in breast cancer patients, the secretions from breast cancer cells increase LINE-1 methylation in cancer stromal cells [8]. DNA methylation is one of the most important epigenetic signatures in cancer because of its influence on gene transcriptional activities, including epigenetic silencing of tumor suppressor genes through hypermethylation at the $\mathrm{CpG}$ regions and activation of oncogenes through gene-wide hypomethylation [7]. Recent evidence suggests that the detection of methylated circulating cell-free DNA in the peripheral blood of cancer patients may be a promising quantitative and noninvasive method for cancer diagnosis [9].

Variety of techniques have been developed to detect the DNA methylation; each has its own advantages and limitations. Genome-wide methylation sequencing or microarray-based profiling is often used to identify candidate biomarkers. The performance of a specific biomarker or a limited panel of biomarkers in larger cohorts is typically assessed using locus-specific assays such as quantitative MSP (qMSP), one-step MSP (OS-MSP) assay, MethyLight assay, and pyrosequencing, which can detect methylation of known loci with high sensitivity and specificity [10]. The blood-based DNA methylation biomarkers of breast cancer from cell-free DNA are as follows: DNA repair associated (BRCA1) [1114], BRCA2 [12], adenomatous polyposis coli (APC) $[11,13]$, ataxia telangiectasia mutated $(A T M)[11$, 12], Tumor Protein P53 (TP53) [12], glutathione S-transferase pi 1 (GSTP1), retinoic acid receptor beta $2(R A R \beta 2)[11,14]$, and Ras association domain family member 1A (RASSF1A) [11,13,14]. A previous study shows that the intragenic MMP9 methylation in WBCs, caused by the secretions of colorectal cancer cells, is a promising biomarker to be tested in future screening studies of colorectal cancer [15]. However, the molecular mechanisms underlying DNA methylation changes in circulating cells, cancer cells or WBCs remain unclear $[8,9,15$, 16].

In the present study, we aimed to search the tumor-induced DNA methylation in WBCs caused by the secretion of breast cancer cells to be an effective tumor marker for breast cancer screening with high sensitivity and specificity.

\section{MATERIALS AND METHODS}

\section{Study participants}

The study participants for the co-culture method consisted of 9 healthy women, as shown in Table S1. The study participants for preliminary test of methylated CpG sites invalidation genes using MSP consisted of 5 breast cancer patients and 5 healthy women, which are the same participants of the SYBR green-based RT-MSP of RHEB, as shown in Table S1. The study participants for SYBR greenbased RT-MSP of RHEB consisted of 200 female breast cancer patients in all stages and 200 healthy women. They were recruited between March 2015 to October 2017. Ethics approval and consent to participate were approved by the Ethics Committee of NCI, Thailand (029/2559) and the Institutional Review Board of the Faculty of Medicine, Chulalongkorn University, Thailand (IRB No. 562/62). In healthy control group, the inclusion criteria were healthy female, no previous history of breast cancer and no family history of breast cancer. In breast cancer group, the inclusion criteria were new cases of female breast cancer, treatment not started, no previous history of breast cancer or recurrent tumor and no history of other cancers. The exclusion criteria of two groups were other cancer patients or other serious diseases. Sample size was calculated from the results of preliminary test of validation genes using MSP and threshold cycle of methylation values $\left(\mathrm{C}_{\mathrm{T} \text { Met }}\right)$ using a two-tailed independent $t$-test with $90 \%$ power and alpha $=0.05,4$ participants per group were required.

\section{Sample collection}

The blood samples for the co-culture method were collected in $4 \times 6 \mathrm{ml} \mathrm{K3}$ EDTA tubes (VACUETTE, Greiner Bio-One GmbH, Kremsmünster, Austria) per person. All 400 blood samples (3 ml) for validation and testing of DNA methylation biomarkers were collected and centrifuged at $1500 \mathrm{rpm}$ for $10 \mathrm{~min}$ to collect WBCs. 


\section{Identification of aberrant DNA methylated genes in breast cancer}

The methods used to identify aberrant DNA methylated genes in breast cancer consist of co-culture method and DNA methylation microarray. Laboratory experiments and analyses of the results of the two methods were performed by Dr. Charoenchai Puttipanyalears in 2016.

\section{PBMC isolation}

The healthy control PBMCs were isolated from whole blood by Ficoll-Paque PLUS (Stemcell Technologies, BC, Canada). In the first step, the whole blood was diluted with an equal volume of phosphate buffered saline (PBS) (Gibco, MA, USA) and carefully layered the diluted blood on top of $4 \mathrm{ml}$ Ficoll-Paque PLUS. Centrifuged at $2800 \mathrm{rpm}$ for $15 \mathrm{~min}$ at $16^{\circ} \mathrm{C}$ and carefully transferred the cloudy interface layer to a $1.5 \mathrm{ml}$ tube. The PBMCs platelets were separated by centrifuged at $500 \times g$ for $7 \mathrm{~min}$ at $16^{\circ} \mathrm{C}$. Washed the PBMCs platelets with $1 \mathrm{ml}$ of PBS. Resuspended the PBMCs platelets with $1 \mathrm{ml}$ of Dulbecco's Modified Eagle's medium (DMEM) (Gibco, MA, USA).

\section{Cell line culture and co-culture}

Cultured 3 breast cancer cell lines are representatives of different types of breast cancer patients. MCF7 (Luminal A: ER+, PR+, HER2-, and wild type p53) (HTB-22 ${ }^{\mathrm{TM}}$ ), MDA-MB-231 (Triple negative: ER-, PR-, HER2-, and mutant p53) (HTB$26^{\mathrm{TM}}$ ) and T47D (Luminal A: ER+, PR+, HER2-, and mutant p53) (HTB-133 ${ }^{\mathrm{TM}}$ ) were obtained from ATCC (VA, USA). All cell lines were grown in DMEM supplemented with $10 \%$ fetal bovine serum (FBS) (Gibco, MA, USA) and 1\% penicillin (10000 Units/ml)-streptomycin (10000 $\mu \mathrm{g} / \mathrm{ml}$ ) (Gibco, MA, USA). The cell lines were grown in a humidified incubator with $95 \%$ air $/ 5 \% \mathrm{CO}_{2}$ atmosphere at $37^{\circ} \mathrm{C}$. Harvested the cell lines with $500 \mu \mathrm{l}$ of $0.25 \%$ Trypsin-EDTA (1X) (Gibco, MA, USA) and centrifuged at $500 \times g$ for $5 \mathrm{~min}$.

The co-culture method was used to study the effects of the secretion from breast cancer cells on healthy control PBMCs. The breast cancer cell lines and the healthy control PBMCs were co-cultured in $24 \mathrm{~mm}$ Transwell with $0.4 \mu \mathrm{m}$ pore Polycarbonate membrane cell culture inserts (Corning, NY, USA). The $5 \times 10^{4}$ cells/well of breast cancer cells were seeded in 24-well plates in DMEM supplemented with $10 \%$ FBS for $24 \mathrm{~h}$. Subsequently, the $1 \times$
$10^{5}$ cells/well of healthy control PBMCs were cocultured into each Transwell for $4 \mathrm{~h}$. In the final steps, the induced PBMCs were harvested. Washed the induced PBMCs twice with $500 \mu l$ PBS.

\section{DNA methylation microarray}

DNA was extracted from the induced PBMCs and bisulfite converted before the process of DNA methylation microarray, which was performed at the Department of Epigenetics, NCCRI, Tokyo, Japan. The microarray-based DNA methylation profiling was performed by using Illumina Infinium $\mathrm{Hu}-$ man Methylation 450K BeadChip Kit (Illumina, CA, USA). The Infinium HD Methylation process was done according to the Infinium HD Methylation process using Infinium Methylation BeadChips in Illumina 15019519 Revision B manual. The types of experiment were as follows: GSE was DNA methylation profiling by array, GPL was GPL8490 and GSM was bisulfite converted DNA from whole blood. The Illumina GenomeStudio Methylation Module (Illumina, CA, USA) was used to analyze intensities to assign site-specific DNA methylation P-values to each $\mathrm{CpG}$ site.

\section{Retrieving GenBank data}

Microarray-based DNA methylation profiles were retrieved via the National Center for Biotechnology Information (NCBI) GEO database (http://www. ncbi.nlmNih.gov/geo). "DNA methylation", "Breast cancer" and "Blood" were used to search. The search was restricted to the following specific fields: GSE was DNA methylation profiling by array, GPL was GPL8490 and GSM was bisulfite converted DNA from whole blood. GSE32396 [17] and GSE57285 [18] were used to represent the DNA methylation profiles of blood from breast cancer. GSE32396, containing 60 blood samples, was divided into two groups of the women: BRCA1 mutation and BRCA1 wild type. Each group consisted of 15 breast cancer patients and 15 healthy controls. GSE57285 contained 84 blood samples consisting of 42 healthy women with $B R C A 1$ wild type, 7 healthy women with $B R C A 1$ methylation and 35 breast cancer patients with $B R C A 1$ methylation.

\section{CU-DREAM X}

Connection Up- or Down- Regulation Expression Analysis of Microarrays X (CU-DREAM-X) program was used to compare between the DNA methylation 
profiles of healthy control PBMCs after co-culturing with 3 breast cell lines (The content of this table can be obtained by sending a request to the authors.) and the DNA methylation profiles of WBCs from breast cancer patients. At the beginning, the GSE32396 and GSE57285 template files, in *.xlsx format, were prepared according to the form. The two-tailed hypothesis test was used to analyze the results at statistical significance of 0.05 and the differential methylation was Intragenic Up-Up. All analyzed files were introduced in CU-DREAM X folder on drive $\mathrm{C}$. The program was started by running Command Prompt with "cd c: \CU-DREAMX". The result was an intersect table of upregulated DNA methylation profiles of healthy control PBMCs after co-culturing with 3 breast cell lines and the DNA methylation profiles of WBCs from breast cancer patients in 2 GSEs.

\section{Preliminary test of methylated CpG sites in validation genes using MSP}

\section{DNA extraction and bisulfite treatment}

Genomic DNA (gDNA) was extracted from $100 \mu 1$ of WBC pellets using QuickGene DNA whole blood kit S (DB-S) (KURABO, Osaka, Japan) in Nucleic Acid Isolation System QuickGene-810 (FUJIFILM, Tokyo, Japan) according to the manufacturer's protocol. About $750 \mathrm{ng}$ of gDNA in $20 \mu \mathrm{l}$ total volume was bisulfite converted using the EZ DNA MethylationGold $^{\mathrm{TM}}$ Kit (D5006) (Zymo Research, CA, USA) according to the manufacturer's instructions. Bisulfite conversion was performed on the Thermal Cycler 480 (Perkin Elmer, MA, USA). The thermocycling conditions were as follows: $98^{\circ} \mathrm{C}$ for $10 \mathrm{~min}, 64^{\circ} \mathrm{C}$ for $2.5 \mathrm{~h}$ and $4^{\circ} \mathrm{C}$ for $10 \mathrm{~min}$.

Preliminary tests of all methylated $\mathrm{CpG}$ sites in validation genes were performed to determine the most effective CpG sites and probes for detection of DNA methylation in breast cancer patient bloods using MSP. The primer sequences, annealing temperature and PCR product sizes of all 6 methylated CpG sites were shown in Table S2. The PCR reaction mixture was prepared in $20 \mu \mathrm{l}$ total volume containing $10 \mu \mathrm{l}$ of QPCR Green Master Mix LRox, 2x (Biotechrabbit GmbH, Berlin, Germany), $8.8 \mu \mathrm{l}$ of nuclease free water, $0.1 \mu \mathrm{l}$ of $20 \mu \mathrm{M}$ forward and reverse primer, and $1 \mu \mathrm{l}$ of bisulfite converted DNA. The amplifications were performed on Mastercycler pro S (Eppendorf, Hamburg, Germany). The thermocycling conditions were as follows: initial denaturation at $94^{\circ} \mathrm{C}$ for $5 \mathrm{~min}$, followed by 35 cycles of denaturation at $95^{\circ} \mathrm{C}$ for $1 \mathrm{~min}$, annealing at $53-58^{\circ} \mathrm{C}$ for $1 \mathrm{~min}$, extension at $72^{\circ} \mathrm{C}$ for $1 \mathrm{~min}$, and final extension at $72{ }^{\circ} \mathrm{C}$ for $7 \mathrm{~min}$. The amplified PCR products were run in $8 \%$ acrylamide gel electrophoresis and stained with GelStar Nucleic Acid Gel Stain (Lonza Rockland, ME, USA) for $20 \mathrm{~min}$.

\section{SYBR green-based RT-MSP of RHEB}

The RHEB methylation status was determined by SYBR green-based RT-MSP. The primers were designed to specifically amplify methylated bisulfite converted DNA for the methylation and used unmethylated bisulfite converted DNA as an internal control. RHEB methylation and unmethylation primers (BIONEER, Victoria, Australia) were designed from cg03998173 location in intragenic region. The RHEB methylation primers were: forward primer $5^{\prime}$-CGTTAGTTTTGGTGTTCGTTTC- $3^{\prime}$ and reward primer $5^{\prime}$-CGACGCTATTCCAAAAAATACG$3^{\prime}$. The RHEB unmethylation primers were: forward primer $5^{\prime}$-GTTTTGTTAGTTTTGGTGTTTGTTTT- $3^{\prime}$ and reward primer $5^{\prime}$-CCCCAACACTATTCCAAAAA ATACA-3 ${ }^{\prime}$. The PCR reaction mixture was prepared according to the MSP method. Each of the methylated and unmethylated reactions was performed in separate reaction wells in triplicate. The RHEB unmethylation was used as internal control. The amplifications were performed on QuantStudio6 Flex Real-Time PCR System (Applied Biosystems, CA, USA). The experimental setup of the instrument for reaction: fast 96-well $(0.1 \mathrm{ml})$ block, Comparative $\mathrm{C}_{\mathrm{T}}\left(\Delta \Delta \mathrm{C}_{\mathrm{T}}\right)$, SYBR ${ }^{\circledR}$ Green Reagents, and run standard including melt curve. The thermocycling conditions were as follows: initial denaturation at $95^{\circ} \mathrm{C}$ for $2 \mathrm{~min}$, followed by 40 cycles of denaturation at $95^{\circ} \mathrm{C}$ for $15 \mathrm{~s}$, annealing/extension at $60^{\circ} \mathrm{C}$ for $30 \mathrm{~s}$ and melt curve at $95^{\circ} \mathrm{C}$ for $15 \mathrm{~s}, 60^{\circ} \mathrm{C}$ for $1 \mathrm{~min}, 95^{\circ} \mathrm{C}$ for $30 \mathrm{~s}$.

\section{Statistical analysis}

All statistical analyses were performed using SPSS (Statistical Package for the Social Sciences for Windows (IBM, NY, USA). The chi-squared statistic was used to test the independence of two populations between breast cancer patients and healthy controls. The two-tailed hypotheses testing was performed to analyze the results from CU-DREAM X and determine significant differences in DNA methylation changes in WBCs from breast cancer patients and healthy controls. Receiver operating characteristic (ROC) curve was used to evaluate the RHEB methylation as tumor marker for breast cancer screening. 
Table 1 Baseline characteristics of breast cancer patients $(n=200)$.

\begin{tabular}{lr}
\hline Characteristic & $\mathrm{N}(\%)$ \\
\hline Age (years) & $2(1.0)$ \\
$21-30$ & $33(16.5)$ \\
$31-40$ & $64(32.0)$ \\
$41-50$ & $66(33.0)$ \\
$51-60$ & $29(14.5)$ \\
$61-70$ & $5(2.5)$ \\
$71-80$ & $1(0.5)$ \\
$81-90$ & \\
\hline
\end{tabular}

Histological type

Invasive ductal carcinoma

Invasive lobular carcinoma

$154(77.0)$

$9(4.5)$

Invasive carcinoma

$3(1.5)$

Invasive ductal carcinoma and mucinous

carcinoma

Invasive papillary carcinoma

Invasive micropapillary carcinoma

Ductal carcinoma in situ (DCIS)

Mucinous carcinoma

2 (1.0)

$1(0.5)$

$1(0.5)$

$11(5.5)$

$5(2.5)$

$1(0.5)$

$1(0.5)$

Intracystic papillary carcinoma

$1(0.5)$

Metaplastic carcinoma with chondroid

differentiation

Malignant phyllodes tumor

$1(0.5)$

Fibroadenoma

$1(0.5)$

Unknown

$9(4.5)$

\begin{tabular}{lr}
\hline Stage & \\
Fibroadenoma & $1(0.5)$ \\
Stage 0 & $9(4.5)$ \\
Stage 1A & $29(14.5)$ \\
Stage 1B & $1(0.5)$ \\
Stage 2A & $36(18.0)$ \\
Stage 2B & $36(18.0)$ \\
Stage 3A & $20(10.0)$ \\
Stage 3B & $22(11.0)$ \\
Stage 3C & $14(7.0)$ \\
Stage 4 & $32(16.0)$ \\
\hline Molecular subtype & \\
Luminal A & $11(5.5)$ \\
Luminal B (Her-2 Negative) & $34(17.0)$ \\
Luminal B (Her-2 Positive) & $78(39.0)$ \\
Her-2 Positive & $28(14.0)$ \\
Luminal A or B & $3(1.5)$ \\
Triple Negative & $20(10.0)$ \\
Unknown & $26(13.0)$ \\
\hline
\end{tabular}

\section{RESULTS}

\section{Characteristics of study participants}

The study participants consisted of 200 female breast cancer patients in all stages with mean age of $50.88 \pm 10.66$ years (ranged between 26 and 85 years) and 200 healthy controls with mean age of $39.01 \pm 11.32$ years (ranged between 19 and 68 years). $65 \%$ of the breast cancer patients were between 41 and 60 years old. The histological type in $77 \%$ of breast cancer patients was invasive ductal carcinoma. The stages of breast cancer patients according to the Tumor-Node-Metastasis (TNM) classification were $36 \%$ of stages $2 \mathrm{~A}$ and $2 \mathrm{~B}$ ( $18 \%$ per stage), $16 \%$ of stage $4,14.5 \%$ of stage $1 \mathrm{~A}$, and other stages. The baseline characteristics of 200 breast cancer patients were shown in Table 1.

\section{Identification of aberrant DNA methylated genes in breast cancer}

The flowchart of our study was illustrated in Fig. 1. The DNA methylation profiles of 9 healthy control PBMCs after co-culturing with 3 breast cell lines (MCF7, MDA-MB-231 and T47D) (The content of this table can be obtained by sending a request to authors.) and the DNA methylation profiles of WBCs from breast cancer patients in 2 GSEs (GSE32396 and GSE57285) were bioinformatics analyzed using CU-DREAM X to identify the aberrant DNA methylated genes in breast cancer. The candidate genes were collected from the overlapping genes of 3 DNA methylation profiling, which were methylated at the same intragenic locations with statistical significance (P-values $<0.05$ and odd ratio $>1$ ). The results were presented in Table 2.

The validation genes were selected from the most common genes in the same blood type in both GSEs and all 3 breast cancer cell lines of all experiments. All 40 candidate genes from all 12 experiments were statistically significant (P-values $<0.05$ and odd ratio $>1$ ). Nine in Like (NINL), the most common gene in 9 out of 12 experiments, was selected as a validation gene. G Protein-Coupled Receptor 39 (GPR39) and MTORC1 Binding (RHEB) of a Ras Homolog gene family were selected as validation genes as they were the most common genes in all 6 experiments of BRCA1 wild type in both GSEs and all 3 breast cancer cells line. Each validation gene had two methylated CpG sites as follows: (1) cg09088834 and cg17729667 located in NINL, (2) cg07785936 and cg24659201 located in GPR39 and (3) cg03998173 and cg21134096 located in RHEB.

\section{Preliminary test of methylated CpG sites in validation genes using MSP}

The most effective CpG sites and probes for detection of DNA methylation in breast cancer pa- 


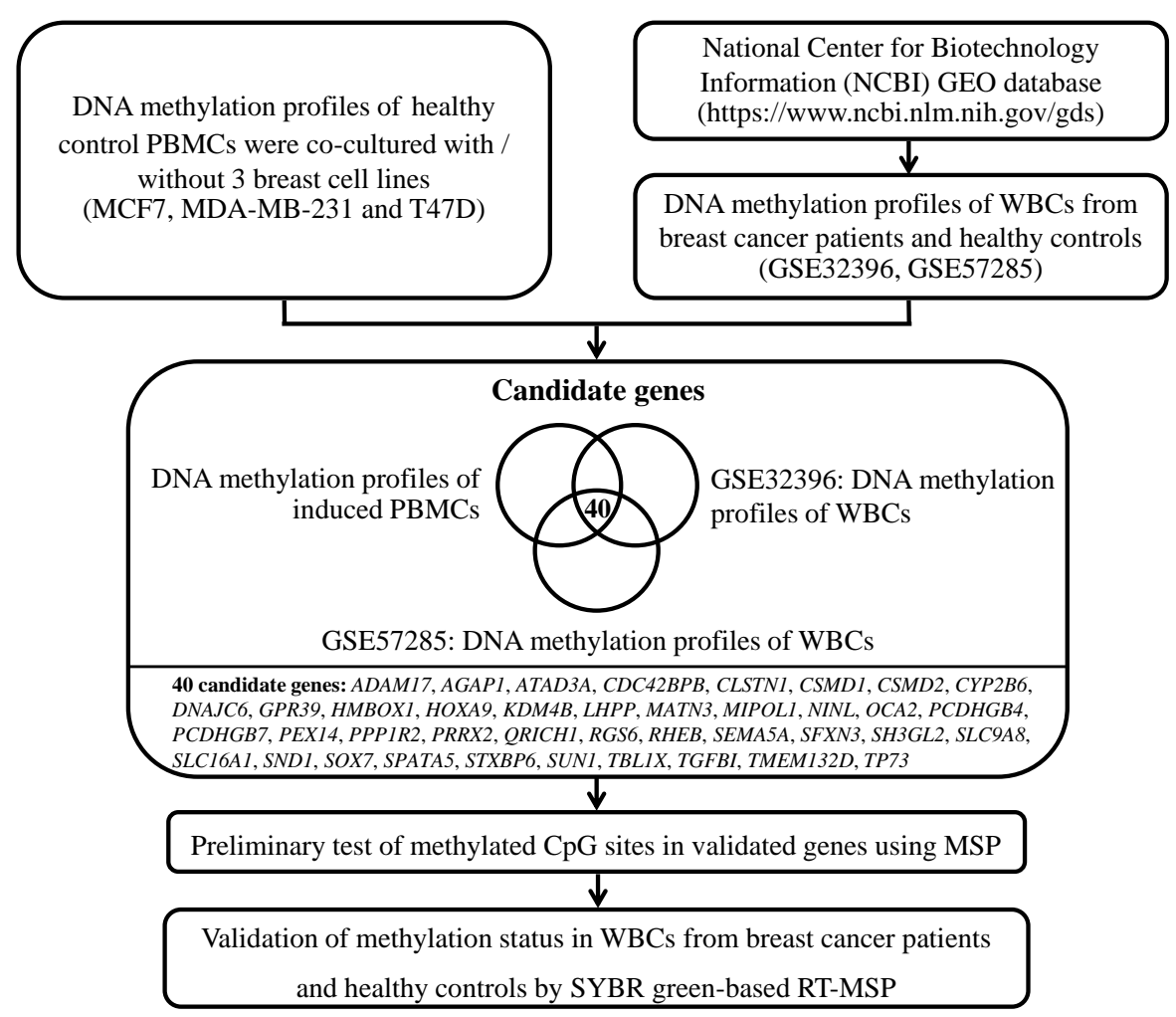

Fig. 1 The flowchart depicting the methodology employed in this study. We identified the aberrant DNA methylated genes in breast cancer by co-culture the healthy controls PBMCs with 3 breast cancer cell lines. Microarray-based DNA methylation profiles of induced PBMCs (The content of this table can be obtained by request to authors) and the DNA methylation profiles of WBCs from breast cancer patients in 2 GSEs (GSE32396 and GSE57285) were bioinformatic analyzed using CU-DREAM X. The 40 candidate genes were collected from the overlapping genes of the 3 data groups, which were hypermethylated genes with P-values $<0.05$ and odd ratio $>1$. All methylated CpG sites in validation genes were selected for preliminary test to determine the most effective CpG sites and probes for detection of DNA methylation in breast cancer patient bloods using MSP. Validation of methylation status in WBCs from breast cancer patients and healthy controls by SYBR green-based RT-MSP.

Table 2 Connection upregulation analysis of microarrays of DNA methylation changes in healthy control PBMCs after co-culturing with 3 breast cell lines and WBCs from breast cancer patients in 2 GSEs (GSE32396 and GSE57285).

\begin{tabular}{lcrrc}
\hline GSEs and blood type & Experiment & No. of genes & OR (95\% CI) & P-value \\
\hline GSE57285; MA1: BRCA1 mutation & MCF7_Intragenic_Up_MA1_Up & 262 & $1.53(1.31-1.77)$ & $2.52 \times 10^{-8}$ \\
GSE57285; MA2: BRCA1 wild type & MCF7_Intragenic_Up_MA2_Up & 265 & $1.28(1.11-1.48)$ & $9.15 \times 10^{-4}$ \\
GSE32396; MA3: BRCA1 mutation & MCF7_Intragenic_Up_MA3_Up & 118 & $1.71(1.39-2.11)$ & $3.78 \times 10^{-7}$ \\
GSE32396; MA4: BRCA1 wild type & MCF7_Intragenic_Up_MA4_Up & 79 & $1.85(1.43-2.38)$ & $1.58 \times 10^{-6}$ \\
GSE57285; MA1: BRCA1 mutation & M231_Intragenic_Up_MA1_Up & 243 & $1.42(1.22-1.67)$ & $1.19 \times 10^{-5}$ \\
GSE57285; MA2: BRCA1 wild type & M231_Intragenic_Up_MA2_Up & 258 & $1.25(1.07-1.46)$ & $4.08 \times 10^{-3}$ \\
GSE32396; MA3: BRCA1 mutation & M231_Intragenic_Up_MA3_Up & 125 & $1.62(1.30-2.02)$ & $1.60 \times 10^{-5}$ \\
GSE32396; MA4: BRCA1 wild type & M231_Intragenic_Up_MA4_Up & 85 & $1.45(1.13-1.86)$ & $3.68 \times 10^{-3}$ \\
GSE57285; MA1: BRCA1 mutation & T47D_Intragenic_Up_MA1_Up & 237 & $1.56(1.34-1.82)$ & $1.05 \times 10^{-8}$ \\
GSE57285; MA2: BRCA1 wild type & T47D_Intragenic_Up_MA2_Up & 244 & $1.66(1.42-1.93)$ & $5.44 \times 10^{-11}$ \\
GSE32396; MA3: BRCA1 mutation & T47D_Intragenic_Up_MA3_Up & 113 & $1.52(1.24-1.88)$ & $7.57 \times 10^{-5}$ \\
GSE32396; MA4: BRCA1 wild type & T47D_Intragenic_Up_MA4_Up & 78 & $1.85(1.44-2.38)$ & $9.12 \times 10^{-7}$ \\
\hline
\end{tabular}

$\mathrm{MA}=$ microarray; OR = odds ratio; 95\% CI = 95\% confidence interval. Each GSE was separated by blood types into BRCA1 mutation and BRCA1 wild type. 
tient blood samples were determined by preliminary test in all 6 methylated CpG sites using MSP. The preliminary test of 6 methylated CpG sites were estimated from the bands in $8 \%$ acrylamide gel from 5 breast cancer patients and 5 healthy controls, which were the same samples in all methylated CpG sites. The sensitivity and specificity of each methylated $\mathrm{CpG}$ probe were calculated from number of methylated and unmethylated bands. The sensitivity and specificity of 6 methylated CpG probes were as follows: $100 \%$ and $20 \%$, respectively, for cg09088834, cg24659201 and $\operatorname{cg} 21134096 ; 100 \%$ and 40\%, respectively, for cg17729667; 100\% and $80 \%$, respectively, for cg03998173; and no detected bands for cg07785936. Therefore, the cg03998173 probe located in RHEB was the most effective CpG probe for detection of DNA methylation in breast cancer patient blood samples in this study. The RHEB (cg03998173) probe was selected as a validation gene to determine the methylation status for detection of breast cancer in blood.

\section{SYBR green-based RT-MSP of RHEB}

The RHEB (cg03998173) methylation status was determined in the WBCs from 200 breast cancer patients in all stages and 200 healthy controls by RTMSP. RHEB methylation was detected in WBCs from 188 (94\%) breast cancer patients and 59 (29.50\%) healthy controls with high sensitivity of $94 \%$ and specificity of $70.50 \%$. The amplification plots of DNA methylation and DNA unmethylation of RHEB were shown in Fig. 2. The melting temperature (Tm) of RHEB unmethylation was $73^{\circ} \mathrm{C}$ and RHEB methylation $77^{\circ} \mathrm{C}$. The RHEB unmethylation was used as internal control. The scatter plots and ROC curve of RHEB methylation between breast cancer patients and healthy controls, as shown in Fig. 3. The 200 female breast cancer patients in all stages had mean $40-C_{T}$ and SEM of $2.89 \pm 0.11$ and the 200 healthy controls mean $40-C_{T}$ and SEM of $1.88 \pm 0.21$. A higher $40-C_{T}$ represents a higher methylation level of RHEB. It is represented as 0 if the RHEB methylation was not detectable after 40 cycles. ROC curve analysis was performed to determine the performance of the RHEB methylation as tumor marker for breast cancer screening. ROC curve was constructed using cutoff value of $40-\mathrm{C}_{\mathrm{T}}$ with area under the ROC curve (AUC) of 0.9453 (P-value $<0.001$ ), as shown in Fig. 3(b). The age difference did not affect RHEB methylation pattern.

\section{DISCUSSION}

DNA methylation is one of the most important epigenetic modification associated with target gene silencing and is correlated with cancer carcinogenesis and progression $[7,19]$. Aberrant DNA methylation is the earliest molecular alteration occurring during carcinogenesis and specific for the malignant state. DNA methylation has been used as a noninvasive biomarker for cancer detection and diagnosis. Therefore, aberrant DNA methylation has been considered as powerful potential biomarkers for cancer diagnosis [20].

Individual cancers have characteristic mechanisms to release the tumor DNA into closely related body fluids. These biological fluids are sources for biomarker investigation. Blood is the most common sample types used to detect the circulating cell-free DNA as cancer biomarkers because blood contains a high volume of genetic materials [10]. A recent study shows that plasma cell-free DNA can be used to predict the prognosis of advanced gastric cancer patients and screening patients with benefit-assisted neoadjuvant chemotherapy for advanced gastric cancer [21]. In another study, the WBCs receive secretory molecules from cancer cells irrespective of the tumor size. The results, between WBCs and PBMCs, indicated similar levels. But to examine methylation status, WBCs isolation is easier and faster than PBMCs. Therefore, WBCs were used, instead of PBMCs. The secretions from cancer cells could alter circulating WBCs and these changes could be used as sensitive circulating tumor markers [15].

We identified the aberrant DNA methylated genes in breast cancer by co-culture the healthy controls PBMCs with 3 breast cancer cell lines (MCF7, MDA-MB-231 and T47D). NINL, GPR39 and RHEB were selected as validation genes.

Nlp (ninein-like (NINL) protein), an important molecule involved in centrosome maturation and spindle formation, plays an important role in tumorigenesis; and its abnormal expression was recently observed in human breast and lung cancers [22]. Nlp is a member of the $\gamma$-tubulin complex binding proteins (GTBPs) and is essential in the process of mitosis. Nlp exhibited certain biological characteristics, including promoting breast tumorigenesis and development [23].

GPR39 is a zinc sensing receptor, which is expressed in several cell types including intestinal epithelial cells (IECs) [24]. GPR39 plays a role in cellular and physiological processes, such as insulin 

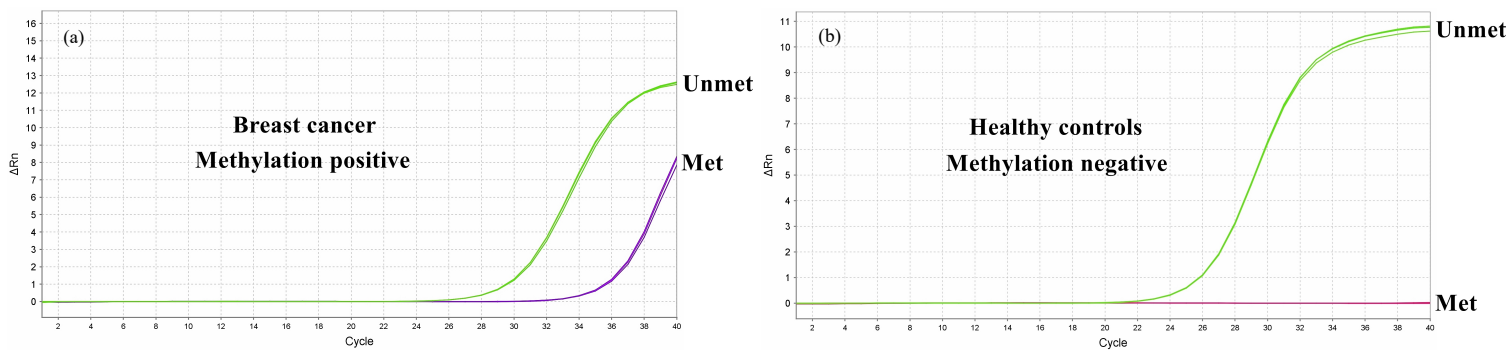

Fig. 2 Amplification plots of $R H E B$ methylation and RHEB unmethylation in breast cancer patients and healthy controls by SYBR green-based RT-MSP. (a) The amplification plot of methylation positive in breast cancer patients. (b) The amplification plot of methylation negative in healthy controls.

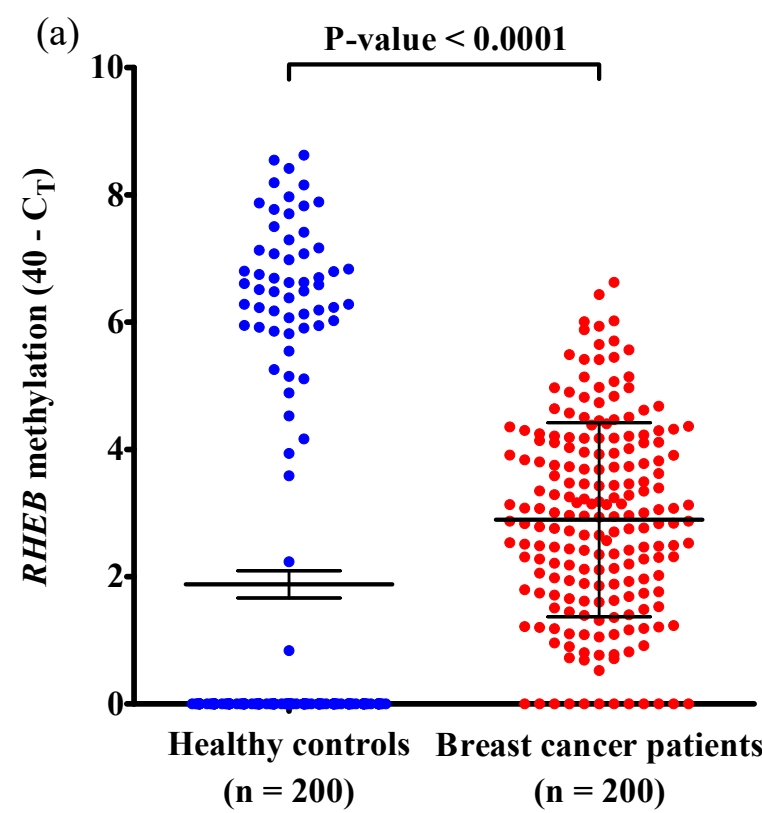

(b)

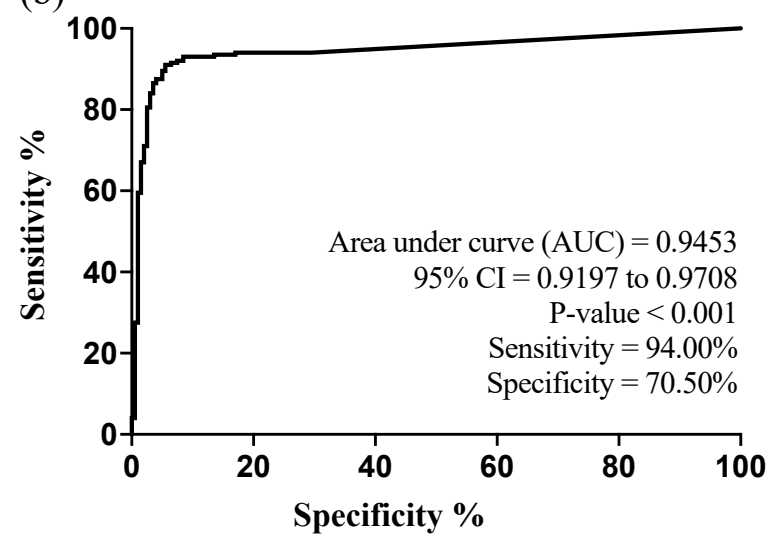

Fig. 3 Scatter plots and ROC curve of RHEB methylation between breast cancer patients and healthy controls: (a) RHEB methylation $\left(40-\mathrm{C}_{\mathrm{T}}\right.$ ) and (b) ROC curve of RHEB methylation. secretion, tumorigenesis, obesity, wound healing, cell death inhibition, and proliferation and differentiation of colonocytes [25]. GPR39 is in signaling by GPCR pathways. GPR39 hypermethylation was found in MDA-MB-231 cells after treatment with resveratrol at $24 \mathrm{~h}$ and $48 \mathrm{~h}$ [26].

$R H E B$, a member of the Ras family of GTPases, has been implicated as an oncogene and may be involved in estrogen-dependent breast cancer [27]. RHEB binds and activates the key metabolic regulator mTORC1, which has an important role in cancer cells. RHEB overexpression in breast and head and neck cancers was a risk factor for cancer progression, independent of HER2 amplification or Phosphatase and Tensin Homolog (PTEN) loss of function in breast cancer or EGFR amplification/overexpression in head and neck cancer [28]. Elevated RHEB expression has been reported in a wide variety of tumors and coupled with mTORC1 hyper-activation, including human breast cancers. RHEB downreglation by FADD deficiency was validated in human breast cancer cell lines MCF-7 and MDA-MB-231. Like FADD, high RHEB expression is also correlated to poor prognosis in human breast cancer [29]. When Rheb mutants were analyzed in blood, it was found that Rheb deficiency had induced a significant increase in the total number of WBCs in peripheral blood, and especially in the Mac- $1^{+}$ myeloid population [30].

The RHEB (cg03998173) methylation status was determined in the WBCs from 200 breast cancer patients in all stages and 200 healthy controls by SYBR green-based RT-MSP. The RHEB methylation were detected in WBCs from $94 \%$ of breast cancer patients and $29.50 \%$ of healthy controls with high sensitivity of $94 \%$ and specificity of $70.50 \%$ (P-value $<0.0001$ ).

There were variety of breast cancer screening biomarkers; but their specificity and sensitivity 
were not high enough for early detection of breast cancer. The Fragile Histidine Triad Diadenosine Triphosphatase (FHIT) hypermethylation in breast cancer was 8.4-folds higher than normal breast tissues [31]. In previous studies, whole-blood DNA methylation markers had been suggested as potential biomarkers for early detection of breast cancer. Hyaluronidase 2 (HYAL2) showed the best discriminative performance with specificity of $90 \%$ and sensitivity of $58.50 \%$ (Validation I), and $63.88 \%$ (Validation II). Another promising candidate is S100 calcium binding protein $\mathrm{P}$ (S100P) with sensitivity of $71.60 \%$ and specificity of $76.60 \%$ [32]. The integration analysis of methylation using the 4gene (RAD50 Double Strand Break Repair Protein (RAD50), Regulator of Telomere Elongation Helicase 1 (RTEL), Telomerase RNA Component (TERC), and Telomeric Repeat Binding Factor 1 (TRF1)) panel as biomarkers for breast cancer detection showed sensitivity of $79.4 \%$ and specificity of $86.2 \%$. When used the methylation and expression of the 4-gene panel showed sensitivity of $83.2 \%$ and specificity of $89 \%$ [33]. The APC/Forkhead Box A1(FOXA1)/RASSF1A methylation panel for detection of breast cancer in plasma achieved $81.82 \%$ sensitivity and $76.92 \%$ specificity. Therefore, the differences in performance of the biomarkers are most likely related to biological sample type (tissue vs. body fluids) and methylation assessment methods [13].

\section{CONCLUSION}

Tumor-induced DNA methylation in WBCs caused by the secretion of breast cancer cells can be an effective tumor marker for breast cancer screening. The RHEB methylation is a new highly sensitive and specific tumor marker from DNA methylation change in white blood cells of breast cancer patient. Therefore, the RHEB methylation may be considered as a tumor marker for breast cancer screening.

\section{Appendix A. Supplementary data}

Supplementary data associated with this article can be found at http://dx.doi.org/10.2306/ scienceasia1513-1874.2021.017.

Acknowledgements: This work was supported by Dr. Kanwalat Chalertpet for technical assistance in MSP and SYBR green-based RT-MSP and Ms. Siriporn Khunsri for technical assistance in bisulfite conversion and SYBR green-based RT-MSP. The present study was supported by the National Research Council of Thailand.

\section{REFERENCES}

1. Bray F, Ferlay J, Soerjomataram I, Siegel R, Torre L, Jemal A (2018) Global cancer statistics 2018: GLOBOCAN estimates of incidence and mortality worldwide for 36 cancers in 185 countries. CA Cancer $J$ Clin 68, 394-424.

2. Imsamran W, Pattatang A, Supattagorn P, Chiawiriyabunya I, Namthaisong K, Wongsena M, Puttawibul P, Chitapanarux I, et al (2018) Cancer in Thailand vol. IX, 2013-2015, National Cancer Institute, Bangkok, Thailand.

3. Strategy and Planning Division (2018) Public Health Statistics A.D. 2017, Office of Permanent Secretary, Ministry of Public Health, Nonthaburi, Thailand.

4. National Cancer Institute (2018) Recommendations of Appropriate Breast Cancer Screening for Thailand, Clinical Practice Guidelines, National Cancer Institute, Bangkok, Thailand.

5. Hocaoglu M, Ersahin AA, Akdeniz E (2017) Evaluation on the practice and behaviour of women applied for gynecology outpatient clinics about screening methods for early diagnosis of breast cancer. Eur $J$ Breast Health 13, 150-155.

6. Coleman C (2017) Early detection and screening for breast cancer. Semin Oncol Nurs 33, 141-155.

7. Loke SY, Lee ASG (2018) The future of blood-based biomarkers for the early detection of breast cancer. Eur J Cancer 92, 54-68.

8. Puttipanyalears C, Kitkumthorn N, Buranapraditkun S, Keelawat S, Mutirangura A (2016) Breast cancer upregulating genes in stromal cells by LINE1 hypermethylation and micrometastatic detection. Epigenomics 8, 475-486.

9. Cheuk IWY, Shin VY, Kwong A (2017) Detection of methylated circulating DNA as noninvasive biomarkers for breast cancer diagnosis. $J$ Breast Cancer 20, 12-19.

10. Leygo C, Williams M, Jin H, Chan M, Chu W, Grusch M, Cheng YY (2017) DNA methylation as a noninvasive epigenetic biomarker for the detection of cancer. Dis Markers 2017, ID 3726595.

11. Li L, Choi JY, Lee KM, Sung H, Park SK, Oze I, Pan KF, You WC, et al (2012) DNA methylation in peripheral blood: a potential biomarker for cancer molecular epidemiology. J Epidemiol 22, 384-394.

12. Joo JE, Dowty JG, Milne RL, Wong EM, Dugué PA, English D, Hopper JL, Goldgar DE, et al (2018) Heritable DNA methylation marks associated with susceptibility to breast cancer. Nat Commun 9, ID 867.

13. Salta S, Nunes SP, Fontes-Sousa M, Lopes P, Freitas M, Caldas M, Antunes L, Castro F, et al (2018) A DNA methylation-based test for breast cancer detection in circulating cell-free DNA. J Clin Med 7, ID 420.

14. Cui X, Cao L, Huang Y, Bai D, Huang S, Lin M, Yang $\mathrm{Q}$, Lu TJ, et al (2018) In vitro diagnosis of DNA 
methylation biomarkers with digital PCR in breast tumors. Analyst 143, 3011-3020.

15. Boonsongserm P, Angsuwatcharakon P, Puttipanyalears C, Aporntewan C, Kongruttanachok N, Aksornkitti V, Kitkumthorn N, Mutirangura A (2019) Tumor-induced DNA methylation in the white blood cells of patients with colorectal cancer. Oncol Lett 18, 3039-3048.

16. Jiang Z, Lai Y, Beaver JM, Tsegay PS, Zhao ML, Horton JK, Zamora M, Rein HL, et al (2020) Oxidative DNA damage modulates DNA methylation pattern in human breast cancer 1 (BRCA1) gene via the crosstalk between DNA polymerase $\beta$ and a de novo DNA methyltransferase. Cells 9, ID 225.

17. Zhuang J, Jones A, Lee SH, Ng E, Fiegl H, Zikan M, Cibula D, Sargent A, et al (2012) The dynamics and prognostic potential of DNA methylation changes at stem cell gene loci in women's cancer. PLoS Genet 8, e1002517.

18. Anjum S, Fourkala EO, Zikan M, Wong A, GentryMaharaj A, Jones A, Hardy R, Cibula D, et al (2014) A BRCA1-mutation associated DNA methylation signature in blood cells predicts sporadic breast cancer incidence and survival. Genome Med 6, ID 47.

19. Ye M, Huang T, Ying Y, Li J, Yang P, Ni C, Zhou C, Chen $S$ (2017) Detection of 14-3-3 sigma $(\sigma)$ promoter methylation as a noninvasive biomarker using blood samples for breast cancer diagnosis. Oncotarget $\mathbf{8}$, 9230-9242.

20. Vu TL, Nguyen TT, Doan VTH, Vo LTT (2018) Methylation profiles of BRCA1, RASSF1A and GSTP1 in Vietnamese women with breast cancer. Asian Pac $J$ Cancer Prev 19, 1887-1893.

21. Lin X, Haiyang Z, Bo Y, Hai H, Ke Z, Zou K, Wu XY (2020) Plasma cell-free DNA for screening patients with benefit-assisted neoadjuvant chemotherapy for advanced gastric cancer. ScienceAsia 46, 462-471.

22. Zhao W, Song Y, Xu B, Zhan Q (2012) Overexpression of centrosomal protein Nlp confers breast carcinoma resistance to paclitaxel. Cancer BiolTher 13, 156-163.

23. Liu Q, Wang X, Lv M, Mu D, Wang L, Zuo W, Yu Z (2015) Effects of the ninein-like protein centrosomal protein on breast cancer cell invasion and migration. Mol Med Rep 12, 1659-1664.

24. Pongkorpsakol P, Buasakdi C, Chantivas T, Chatsudthipong V, Muanprasat C (2019) An agonist of a zinc-sensing receptor GPR39 enhances tight junction assembly in intestinal epithelial cells via an AMPK-dependent mechanism. Eur J Pharmacol 842, 306-313.

25. Qiao J, Zhao H, Zhang Y, Peng H, Chen Q, Zhang $\mathrm{H}$, Zheng X, Jin Y, et al (2017) GPR39 is regionspecifically expressed in mouse oviduct correlating with the $\mathrm{Zn}^{2+}$ distribution. Theriogenology 88, 98-105.

26. Medina-Aguilar R, Pérez-Plasencia C, Marchat LA, Gariglio P, García-Mena J, Cuevas SR, Ruíz-García E, de la Vega HA, et al (2016) Methylation landscape of human breast cancer cells in response to dietary compound resveratrol. PLoS One 11, e0157866.

27. Hanker AB, Der CJ (2010) Handbook of cell signaling. In: The Roles of Ras Family Small GTPases in Breast Cancer, 2nd edn, Elsevier, The Netherlands, pp 2763-2772.

28. Lu ZH, Shvartsman MB, Lee AY, Shao JM, Murray MM, Kladney RD, Fan D, Krajewski S, et al (2010) mTOR activator Rheb is frequently overexpressed in human carcinomas and is critical and sufficient for skin epithelial carcinogenesis. Cancer Res 70, 3287-3298.

29. He L, Ren Y, Zheng Q, Wang L, Lai Y, Guan S, Zhang $X$, Zhang R, et al (2016) Fas-associated protein with death domain (FADD) regulates autophagy through promoting the expression of Ras homolog enriched in brain (Rheb) in human breast adenocarcinoma cells. Oncotarget 7, 24572-24584.

30. Peng H, Kasada A, Ueno M, Hoshii T, Tadokoro Y, Nomura N, Ito C, Takase Y, et al (2018) Distinct roles of Rheb and Raptor in activating mTOR complex 1 for the self-renewal of hematopoietic stem cells. Biochem Biophys Res Commun 495, 1129-1135.

31. Sun YS, Zhao Z, Yang ZN, Xu F, Lu HJ, Zhu ZY, Shi W, Jiang J, et al (2017) Risk factors and preventions of breast cancer. Int J Biol Sci 13, 1387-1397.

32. Guan Z, Yu H, Cuk K, Zhang Y, Brenner H (2019) Whole-blood DNA methylation markers in early detection of breast cancer: a systematic literature review. Cancer Epidemiol Biomarkers Prev 28, 496-505.

33. Heng J, Zhang F, Guo X, Tang L, Peng L, Luo X, $\mathrm{Xu} \mathrm{X}$, Wang S, et al (2017) Integrated analysis of promoter methylation and expression of telomere related genes in breast cancer. Oncotarget $\mathbf{8}$, 25442-25454. 


\section{Appendix A. Supplementary data}

Table S1 Data of all study participants in 3 methods consisted of co-culture, preliminary test of methylated CpG sites in validation genes using MSP and SYBR green-based RT-MSP of RHEB.

\begin{tabular}{|c|c|c|c|c|c|c|}
\hline Experiment & Code & Sex & Age & Histological type & Stage & Molecular subtype \\
\hline \multirow{9}{*}{ Co-culture } & A & Female & 23 & - & - & - \\
\hline & B & Female & 35 & - & - & - \\
\hline & $\mathrm{C}$ & Female & 40 & - & - & - \\
\hline & $\mathrm{D}$ & Female & 33 & - & - & - \\
\hline & $\mathrm{E}$ & Female & 40 & - & - & - \\
\hline & $\bar{F}$ & Female & 28 & - & - & - \\
\hline & G & Female & 34 & - & - & - \\
\hline & $\mathrm{H}$ & Female & 42 & - & - & - \\
\hline & I & Female & 30 & - & - & - \\
\hline \multirow{10}{*}{$\begin{array}{l}\text { Preliminary } \\
\text { test of } \\
\text { methylated } \\
\text { CpG sites in } \\
\text { validation } \\
\text { genes using } \\
\text { MSP }\end{array}$} & BrCUN 1 & Female & 38 & - & - & - \\
\hline & BrCUN 2 & Female & 42 & - & - & - \\
\hline & BrCUN 3 & Female & 25 & - & - & - \\
\hline & BrCUN 4 & Female & 50 & - & - & - \\
\hline & BrCUN 5 & Female & 42 & - & - & - \\
\hline & BrCU 1 & Female & 57 & Invasive carcinoma of no special type & $2 \mathrm{~B}$ & Luminal B (Her-2 Positive) \\
\hline & BrCU 2 & Female & 42 & Invasive carcinoma NST with medullary features & $2 \mathrm{~A}$ & Triple Negative \\
\hline & BrCU 3 & Female & 51 & Invasive ductal carcinoma & $2 \mathrm{~A}$ & Triple Negative \\
\hline & BrCU 4 & Female & 45 & Fibroadenoma & Benign & $n^{2}-$ \\
\hline & BrCU 5 & Female & 85 & $\begin{array}{l}\text { Mixed invasive ductal carcinoma } \\
\text { and mucinous carcinoma }\end{array}$ & $2 \mathrm{~A}$ & Luminal B (Her-2 Negative) \\
\hline \multirow{47}{*}{$\begin{array}{l}\text { SYBR } \\
\text { green-based } \\
\text { RT-MSP of } \\
\text { RHEB }\end{array}$} & BrCU 1 & Female & 57 & Invasive carcinoma of no special type & $2 \mathrm{~B}$ & Luminal B (Her-2 Positive) \\
\hline & BrCU 2 & Female & 42 & Invasive carcinoma NST with medullary features & $2 \mathrm{~A}$ & Triple Negative \\
\hline & BrCU 3 & Female & 51 & Invasive ductal carcinoma & $2 \mathrm{~A}$ & Triple Negative \\
\hline & BrCU 4 & Female & 45 & Fibroadenoma & Benign & 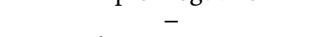 \\
\hline & BrCU 5 & Female & 85 & $\begin{array}{l}\text { Mixed invasive ductal carcinoma } \\
\text { and mucinous carcinoma }\end{array}$ & $2 \mathrm{~A}$ & Luminal B (Her-2 Negative) \\
\hline & BrCU 6 & Female & 58 & Invasive ductal carcinoma & 4 & Luminal B (Her-2 Positive) \\
\hline & BrCU 7 & Female & 70 & Invasive lobular carcinoma, & $1 \mathrm{~A}$ & Luminal B (Her-2 Positive) \\
\hline & BrCU 8 & Female & 35 & Invasive ductal carcinoma & 2B & Luminal B (Her-2 Positive) \\
\hline & BrCU 9 & Female & 40 & Invasive ductal carcinoma & $2 \mathrm{~A}$ & Luminal B (Her-2 Negative) \\
\hline & BrCU 10 & Female & 54 & Invasive ductal carcinoma with extensive DCIS & 2B & Her-2 Positive \\
\hline & BrCU 11 & Female & 70 & - & $2 \mathrm{~A}$ & - \\
\hline & BrCU 12 & Female & 43 & Invasive ductal carcinoma & 4 & Luminal B (Her-2 Positive) \\
\hline & BrCU 13 & Female & 51 & Invasive ductal carcinoma & 2B & - \\
\hline & BrCU 14 & Female & 44 & Invasive ductal carcinoma and DCIS & $3 \mathrm{~A}$ & Luminal B (Her-2 Positive) \\
\hline & BrCU 15 & Female & 68 & Invasive ductal carcinoma & $2 \mathrm{~B}$ & Triple Negative \\
\hline & BrCU 16 & Female & 47 & Mucinous carcinoma & $1 \mathrm{~A}$ & Luminal A \\
\hline & BrCU 17 & Female & 48 & Poorly differentiated adenocarcinoma & 3B & Her-2 Positive \\
\hline & BrCU 18 & Female & 44 & Invasive ductal carcinoma and minimal DCIS & $2 \mathrm{~B}$ & Luminal B (Her-2 Negative) \\
\hline & BrCU 19 & Female & 38 & Invasive ductal carcinoma & $2 \mathrm{~A}$ & Luminal B (Her-2 Positive) \\
\hline & BrCU 20 & Female & 59 & Invasive ductal carcinoma and DCIS & $2 \mathrm{~B}$ & Luminal B (Her-2 Positive) \\
\hline & BrCU 21 & Female & 57 & Nonpalpable breast mass & $2 \mathrm{~A}$ & - \\
\hline & BrCU 22 & Female & 44 & Invasive carcinoma of no special type & 4 & Her-2 Positive \\
\hline & BrCU 23 & Female & 52 & Invasive ductal carcinoma & 3B & Luminal B (Her-2 Positive) \\
\hline & BrCU 24 & Female & 46 & Invasive ductal carcinoma & $3 \mathrm{~B}$ & Her-2 Positive \\
\hline & BrCU 25 & Female & 54 & Invasive ductal carcinoma & $3 C$ & Luminal B (Her-2 Positive) \\
\hline & BrCU 26 & Female & 35 & Invasive ductal carcinoma & $3 B$ & Luminal B (Her-2 Positive) \\
\hline & BrCU 27 & Female & 33 & Invasive ductal carcinoma & $3 B$ & Luminal B (Her-2 Negative) \\
\hline & BrCU 28 & Female & 36 & Invasive carcinoma of no special type & $3 \mathrm{~A}$ & Luminal B (Her-2 Positive) \\
\hline & BrCU 29 & Female & 43 & Invasive lobular carcinoma & $1 \mathrm{~A}$ & Luminal B (Her-2 Positive) \\
\hline & BrCU 30 & Female & 55 & Invasive ductal carcinoma & $2 \mathrm{~A}$ & Her-2 Positive \\
\hline & BrCU 31 & Female & 51 & - & $1 \mathrm{~A}$ & - \\
\hline & BrCU 32 & Female & 67 & Invasive ductal carcinoma & $1 \mathrm{~A}$ & Luminal B (Her-2 Negative) \\
\hline & BrCU 33 & Female & 49 & Invasive ductal carcinoma & $3 C$ & Luminal B (Her-2 Positive) \\
\hline & BrCU 34 & Female & 57 & Invasive ductal carcinoma & 3B & Luminal B (Her-2 Negative) \\
\hline & BrCU 35 & Female & 72 & Invasive ductal carcinoma & $3 \mathrm{~B}$ & Luminal B (Her-2 Negative) \\
\hline & BrCU 36 & Female & 51 & Invasive ductal carcinoma & $2 \mathrm{~A}$ & Triple Negative \\
\hline & BrCU 37 & Female & 59 & Invasive ductal carcinoma & $2 \mathrm{~B}$ & Luminal B (Her-2 Positive) \\
\hline & BrCU 38 & Female & 45 & Invasive lobular carcinoma & $2 \mathrm{~B}$ & Luminal B (Her-2 Negative) \\
\hline & BrCU 39 & Female & 37 & Ductal carcinoma in situ & 0 & - \\
\hline & BrCU 40 & Female & 55 & Invasive ductal carcinoma & 4 & Her-2 Positive \\
\hline & BrCU 41 & Female & 66 & Invasive ductal carcinoma & $2 \mathrm{~A}$ & Luminal A \\
\hline & BrCU 42 & Female & 51 & Invasive ductal carcinoma & 3B & Luminal B (Her-2 Positive) \\
\hline & BrCU 43 & Female & 46 & Invasive lobular carcinoma & $1 \mathrm{~A}$ & - \\
\hline & BrCU 44 & Female & 62 & Invasive ductal cardinoma & 4 & Her-2 Positive \\
\hline & BrCU 45 & Female & 37 & Invasive ductal carcinoma & $2 \mathrm{~A}$ & Luminal B (Her-2 Negative) \\
\hline & $\mathrm{BrCU} 46$ & Female & 48 & Invasive ductal carcinoma & $3 \mathrm{~A}$ & Luminal B (Her-2 Negative) \\
\hline & BrCU 47 & Female & 49 & Invasive ductal carcinoma & $1 \mathrm{~A}$ & Luminal B (Her-2 Positive) \\
\hline
\end{tabular}


Table S1 Continued ...

\begin{tabular}{|c|c|c|c|c|c|c|}
\hline Experiment & Code & Sex & Age & Histological type & Stage & Molecular subtype \\
\hline SYBR & BrCU 48 & Female & 52 & Invasive ductal carcinoma & $2 \mathrm{~A}$ & Luminal B (Her-2 Positive) \\
\hline green-based & BrCU 49 & Female & 51 & Invasive ductal carcinoma and DCIS & $3 \mathrm{~A}$ & Luminal B (Her-2 Positive) \\
\hline RT-MSP of & BrCU 50 & Female & 35 & Invasive ductal carcinoma & $1 \mathrm{~A}$ & Luminal B (Her-2 Positive) \\
\hline \multirow[t]{75}{*}{ RHEB } & BrCU 51 & Female & 60 & Invasive ductal carcinoma & 4 & Luminal B (Her-2 Positive) \\
\hline & BrCU 52 & Female & 40 & Invasive ductal carcinoma & $2 \mathrm{~A}$ & Luminal B (Her-2 Negative) \\
\hline & BrCU 53 & Female & 43 & Invasive ductal carcinoma & $3 \mathrm{~B}$ & - \\
\hline & BrCU 54 & Female & 37 & Invasive ductal carcinoma & 4 & Triple Negative \\
\hline & BrCU 55 & Female & 61 & Invasive ductal carcinoma and DCIS & $1 \mathrm{~A}$ & Her-2 Positive \\
\hline & BrCU 56 & Female & 54 & Invasive ductal carcinoma & 3B & Her-2 Positive \\
\hline & BrCU 57 & Female & 48 & Invasive ductal carcinoma & $3 C$ & Triple Negative \\
\hline & BrCU 58 & Female & 35 & Invasive ductal carcinoma & $1 \mathrm{~A}$ & Triple Negative \\
\hline & BrCU 59 & Female & 34 & Invasive ductal carcinoma & $3 \mathrm{~A}$ & Luminal B (Her-2 Positive) \\
\hline & BrCU 60 & Female & 66 & Invasive ductal carcinama & $3 \mathrm{~A}$ & Luminal B (Her-2 Negative) \\
\hline & BrCU 61 & Female & 71 & Invasive ductal carcinama & $3 B$ & Her-2 Positive \\
\hline & BrCU 62 & Female & 66 & Invasive ductal carcinoma & $3 \mathrm{~A}$ & Luminal B (Her-2 Negative) \\
\hline & BrCU 63 & Female & 37 & Invasive ductal carcinoma & $1 \mathrm{~A}$ & Luminal B (Her-2 Positive) \\
\hline & BrCU 64 & Female & 45 & Invasive ductal carcinoma & $1 \mathrm{~A}$ & Luminal B (Her-2 Positive) \\
\hline & BrCU 65 & Female & 32 & Invasive ductal carcinoma & $2 \mathrm{~B}$ & Luminal B (Her-2 Negative) \\
\hline & BrCU 66 & Female & 53 & Invasive ductal carcinoma & $1 \mathrm{~A}$ & Luminal A \\
\hline & BrCU 67 & Female & 49 & Invasive ductal carcinoma & 4 & Luminal B (Her-2 Negative) \\
\hline & BrCU 68 & Female & 56 & Invasive ductal carcinoma & 3B & Luminal B (Her-2 Positive) \\
\hline & BrCU 69 & Female & 38 & Invasive ductal carcinama & $2 \mathrm{~A}$ & Triple Negative \\
\hline & BrCU 70 & Female & 50 & Invasive lobular carcinoma & 4 & Luminal B (Her-2 Negative) \\
\hline & BrCU 71 & Female & 48 & Invasive ductal carcinoma & $2 \mathrm{~B}$ & Luminal B (Her-2 Negative) \\
\hline & BrCU 72 & Female & 31 & Invasive ductal carcinoma & $2 \mathrm{~B}$ & Her-2 Positive \\
\hline & BrCU 73 & Female & 55 & Invasive ductal carcinoma & 4 & Luminal B (Her-2 Positive) \\
\hline & BrCU 74 & Female & 41 & Invasive lobular carcinoma & $3 \mathrm{~A}$ & Luminal B (Her-2 Negative) \\
\hline & BrCU 75 & Female & 52 & Ductal carcinoma in situ & 0 & Luminal B (Her-2 Positive) \\
\hline & BrCU 76 & Female & 43 & Invasive ductal carcinoma with DCIS & $3 B$ & Triple Negative \\
\hline & BrCU 77 & Female & 68 & Invasive ductal carcinoma & 4 & Luminal B (Her-2 Negative) \\
\hline & BrCU 78 & Female & 56 & Invasive ductal carcinoma & $2 \mathrm{~A}$ & Luminal B (Her-2 Positive) \\
\hline & BrCU 79 & Female & 59 & Invasive ductal carcinoma with DCIS & $3 \mathrm{~A}$ & Luminal A \\
\hline & BrCU 80 & Female & 45 & Lobular carcinoma & $2 \mathrm{~B}$ & - \\
\hline & BrCU 81 & Female & 39 & Invasive ductal carcinoma & $2 \mathrm{~B}$ & Triple Negative \\
\hline & BrCU 82 & Female & 59 & - & $2 \mathrm{~B}$ & - \\
\hline & BrCU 83 & Female & 63 & Metastatic carcinoma & 4 & Luminal B (Her-2 Positive) \\
\hline & BrCU 84 & Female & 40 & Invasive ductal carcinoma & $3 \mathrm{C}$ & Luminal B (Her-2 Positive) \\
\hline & BrCU 85 & Female & 45 & Mucinous carcinoma & $2 \mathrm{~A}$ & Luminal B (Her-2 Negative) \\
\hline & BrCU 86 & Female & 48 & Invasive ductal carcinoma & $3 \mathrm{C}$ & - \\
\hline & BrCU 87 & Female & 55 & Invasive ductal carcinoma & 3C & Luminal B (Her-2 Positive) \\
\hline & BrCU 88 & Female & 69 & Residual invasive ductal carcinama with DCIS & $2 \mathrm{~B}$ & Her-2 Positive \\
\hline & BrCU 89 & Female & 47 & Invasive ductal carcinoma & $3 \mathrm{C}$ & Triple Negative \\
\hline & BrCU 90 & Female & 50 & Invasive ductal carcinoma & 3B & Luminal B (Her-2 Positive) \\
\hline & BrCU 91 & Female & 51 & Invasive ductal carcinoma & 4 & Luminal B (Her-2 Positive) \\
\hline & BrCU 92 & Female & 39 & Invasive ductal carcinoma with DCIS & 2B & Luminal B (Her-2 Positive) \\
\hline & BrCU 93 & Female & 45 & Invasive ductal carcinoma and DCIS & $3 \mathrm{~B}$ & Luminal B (Her-2 Positive) \\
\hline & BrCU 94 & Female & 47 & Invasive ductal carcinoma & $3 \mathrm{~A}$ & Luminal B (Her-2 Positive) \\
\hline & BrCU 95 & Female & 54 & Invasive ductal carcinoma & 4 & Her-2 Positive \\
\hline & BrCU 96 & Female & 51 & Invasive ductal carcinoma & $3 C$ & Her-2 Positive \\
\hline & BrCU 97 & Female & 71 & Invasive ductal carcinoma & $2 \mathrm{~A}$ & Luminal A \\
\hline & BrCU 98 & Female & 55 & Intraductal carcinoma & 4 & - \\
\hline & BrCU 99 & Female & 50 & Invasive ductal carcinoma and DCIS & $3 \mathrm{~A}$ & Her-2 Positive \\
\hline & BrCU 100 & Female & 58 & Invasive ductal carcinoma & 4 & Luminal B (Her-2 Positive) \\
\hline & BrCU 101 & Female & 52 & Invasive ductal carcinoma & 4 & Luminal B (Her-2 Positive) \\
\hline & BrCU 102 & Female & 60 & Invasive ductal carcinoma & $3 \mathrm{~A}$ & Her-2 Positive \\
\hline & BrCU 103 & Female & 55 & Invasive ductal carcinoma & $3 C$ & Luminal B (Her-2 Positive) \\
\hline & BrCU 104 & Female & 70 & Invasive ductal carcinoma & $1 \mathrm{~A}$ & Triple Negative \\
\hline & BrCU 105 & Female & 46 & Invasive ductal carcinoma & $1 \mathrm{~A}$ & 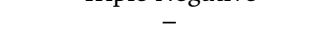 \\
\hline & BrCU 106 & Female & 44 & Invasive lobular carcinoma & $2 \mathrm{~A}$ & Luminal B (Her-2 Negative) \\
\hline & BrCU 107 & Female & 53 & Invasive ductal carcinoma & $2 \mathrm{~B}$ & Her-2 Positive \\
\hline & BrCU 108 & Female & 48 & - & 4 & - \\
\hline & BrCU 109 & Female & 47 & Invasive ductal carcinoma & $3 C$ & Triple Negative \\
\hline & BrCU 110 & Female & 59 & Invasive ductal carcinoma & 4 & Luminal B (Her-2 Positive) \\
\hline & BrCU 111 & Female & 61 & - & 4 & - \\
\hline & BrCU 112 & Female & 48 & - & 2B & - \\
\hline & BrCU 113 & Female & 48 & Invasive ductal carcinoma & $1 \mathrm{~A}$ & Luminal B (Her-2 Negative) \\
\hline & BrCU 114 & Female & 39 & Invasive ductal carcinoma and DCIS & $3 \mathrm{~A}$ & Triple Negative \\
\hline & BrCU 115 & Female & 56 & Malignant phyllodes tumor & $3 \mathrm{~B}$ & - \\
\hline & BrCU 116 & Female & 55 & Invasive ductal carcinoma with DCIS & $2 \mathrm{~A}$ & Luminal B (Her-2 Positive) \\
\hline & BrCU 117 & Female & 52 & Invasive ductal carcinoma with DCIS & $2 \mathrm{~B}$ & Luminal A \\
\hline & BrCU 118 & Female & 46 & Invasive ductal carcinoma & $3 \mathrm{~A}$ & Luminal B (Her-2 Positive) \\
\hline & BrCU 119 & Female & 41 & Invasive ductal carcinoma & $3 B$ & Triple Negative \\
\hline & BrCU 120 & Female & 42 & Invasive ductal carcinoma & $2 \mathrm{~B}$ & Luminal B (Her-2 Positive) \\
\hline & BrCU 121 & Female & 38 & Invasive ductal carcinoma with DCIS & $2 \mathrm{~A}$ & Luminal B (Her-2 Negative) \\
\hline & BrCU 122 & Female & 59 & Invasive ductal carcinoma & $3 \mathrm{~A}$ & Triple Negative \\
\hline & BrCU 123 & Female & 70 & Invasive ductal carcinoma & $1 \mathrm{~A}$ & Triple Negative \\
\hline & BrCU 124 & Female & 48 & Invasive ductal carcinoma & $2 \mathrm{~B}$ & - \\
\hline & BrCU 125 & Female & 56 & Invasive ductal carcinoma with DCIS & $2 \mathrm{~A}$ & Luminal B (Her-2 Positive) \\
\hline
\end{tabular}


Table S1 Continued ...

\begin{tabular}{|c|c|c|c|c|c|c|}
\hline Experiment & Code & Sex & Age & Histological type & Stage & Molecular subtype \\
\hline SYBR & BrCU 126 & Female & 53 & Invasive ductal carcinoma and DCIS & $2 \mathrm{~A}$ & Luminal B (Her-2 Positive) \\
\hline green-based & BrCU 127 & Female & 47 & Invasive ductal carcinoma with DCIS & $2 \mathrm{~B}$ & Luminal A \\
\hline RT-MSP of & BrCU 128 & Female & 48 & Invasive ductal carcinoma & $2 \mathrm{~B}$ & Luminal A \\
\hline \multirow[t]{72}{*}{ RHEB } & BrCU 129 & Female & 44 & Invasive ductal carcinoma & $3 C$ & Luminal B (Her-2 Negative) \\
\hline & BrCU 130 & Female & 36 & Invasive ductal carcinoma and DCIS & $2 \mathrm{~A}$ & Luminal B (Her-2 Negative) \\
\hline & BrCU 131 & Female & 47 & Invasive ductal carcinoma with DCIS & 4 & Luminal B (Her-2 Negative) \\
\hline & BrCU 132 & Female & 68 & Invasive ductal carcinoma & 4 & Luminal B (Her-2 Positive) \\
\hline & BrCU 133 & Female & 33 & Ductal carcinoma in situ & 0 & Luminal B (Her-2 Negative) \\
\hline & BrCU 134 & Female & 78 & Invasive ductal carcinoma & 4 & Luminal B (Her-2 Positive) \\
\hline & BrCU 135 & Female & 42 & Invasive ductal carcinoma & $2 \mathrm{~B}$ & Luminal B (Her-2 Negative) \\
\hline & BrCU 136 & Female & 41 & Mucinous carcinoma & $3 \mathrm{~B}$ & Luminal B (Her-2 Negative) \\
\hline & BrCU 137 & Female & 67 & Invasive ductal carcinoma & $1 \mathrm{~A}$ & Luminal B (Her-2 Positive) \\
\hline & BrCU 138 & Female & 61 & Solid papillary carcinoma in situ & $1 \mathrm{~A}$ & Luminal B (Her-2 Positive) \\
\hline & BrCU 139 & Female & 53 & Infiltrating duct carcinoma & 4 & - \\
\hline & BrCU 140 & Female & 53 & Invasive ductal carcinoma & 4 & Her-2 Positive \\
\hline & BrCU 141 & Female & 47 & Invasive ductal carcinoma & $3 \mathrm{~A}$ & - \\
\hline & BrCU 142 & Female & 46 & Invasive ductal carcinoma & $2 \mathrm{~B}$ & Her-2 Positive \\
\hline & BrCU 143 & Female & 51 & Invasive ductal carcinoma and DCIS & $1 \mathrm{~A}$ & - \\
\hline & BrCU 144 & Female & 58 & Invasive ductal carcinoma and DCIS & $3 \mathrm{C}$ & - \\
\hline & BrCU 145 & Female & 53 & Invasive ductal carcinoma & $3 \mathrm{~A}$ & - \\
\hline & BrCU 146 & Female & 36 & Invasive ductal carcinoma and DCIS & $3 \mathrm{~A}$ & Luminal B (Her-2 Positive) \\
\hline & BrCU 147 & Female & 66 & Invasive ductal carcinoma & $3 C$ & Luminal B (Her-2 Positive) \\
\hline & BrCU 148 & Female & 50 & Invasive ductal carcinoma & $2 \mathrm{~B}$ & Luminal B (Her-2 Positive) \\
\hline & BrCU 149 & Female & 55 & Invasive ductal carcinoma with DCIS & $1 \mathrm{~B}$ & Her-2 Positive \\
\hline & BrCU 150 & Female & 44 & Invasive ductal carcinoma with DCIS & $2 \mathrm{~B}$ & Luminal B (Her-2 Positive) \\
\hline & BrCU 151 & Female & 57 & Ductal carcinoma in situ & 0 & - \\
\hline & BrCU 152 & Female & 51 & Invasive lobular carcinoma & $2 \mathrm{~A}$ & Luminal B (Her-2 Positive) \\
\hline & BrCU 153 & Female & 47 & DCIS with lobular cancerization & $1 \mathrm{~A}$ & Luminal B (Her-2 Positive) \\
\hline & BrCU 154 & Female & 64 & $\begin{array}{l}\text { Invasive micropapillary carcinoma with } \\
\text { invasive ductal carcinoma and DCIS }\end{array}$ & $2 \mathrm{~B}$ & Luminal B (Her-2 Positive) \\
\hline & BrCU 155 & Female & 32 & Invasive ductal carcinoma with DCIS & $2 \mathrm{~A}$ & Luminal B (Her-2 Negative) \\
\hline & BrCU 156 & Female & 63 & Invasive ductal carcinoma & $2 \mathrm{~B}$ & Luminal B (Her-2 Positive) \\
\hline & BrCU 157 & Female & 35 & Invasive ductal carcinoma & 4 & Luminal B (Her-2 Positive) \\
\hline & BrCU 158 & Female & 64 & Microinvasive carcinoma and DCIS & $1 \mathrm{~A}$ & Luminal A \\
\hline & BrCU 159 & Female & 34 & Invasive carcinoma of no special type with DCIS & $2 \mathrm{~B}$ & Luminal B (Her-2 Positive) \\
\hline & BrCU 160 & Female & 60 & Invasive ductal carcinoma & 4 & Luminal B (Her-2 Positive) \\
\hline & BrCU 161 & Female & 49 & Invasive ductal carcinoma with extensive DCIS & $2 \mathrm{~A}$ & Luminal B (Her-2 Positive) \\
\hline & BrCU 162 & Female & 36 & Ductal carcinoma in situ & 0 & Triple Negative \\
\hline & BrCU 163 & Female & 67 & Mucinous carcinoma & $1 \mathrm{~A}$ & Luminal B (Her-2 Positive) \\
\hline & BrCU 164 & Female & 60 & Metaplastic carcinoma with chondroid differentiation & $2 \mathrm{~A}$ & Her-2 Positive \\
\hline & BrCU 165 & Female & 55 & Invasive ductal carcinoma and DCIS & $2 \mathrm{~A}$ & Luminal B (Her-2 Positive) \\
\hline & BrCU 166 & Female & 47 & $\begin{array}{l}\text { Mixed invasive ductal carcinoma and } \\
\text { mucinous carcinoma }\end{array}$ & 3B & Luminal B (Her-2 Positive) \\
\hline & BrCU 167 & Female & 53 & Invasive ductal carcinoma & $3 \mathrm{~A}$ & Her-2 Positive \\
\hline & BrCU 168 & Female & 66 & Ductal carcinoma in situ & 0 & Her-2 Positive \\
\hline & BrCU 169 & Female & 60 & Invasive ductal carcinoma & $2 \mathrm{~B}$ & Luminal B (Her-2 Positive) \\
\hline & BrCU 170 & Female & 46 & Invasive ductal carcinoma & 4 & Luminal B (Her-2 Positive) \\
\hline & BrCU 171 & Female & 59 & Invasive carcinoma of no special type & $1 \mathrm{~A}$ & Luminal B (Her-2 Positive) \\
\hline & BrCU 172 & Female & 45 & Invasive carcinoma of no special type & $2 \mathrm{~B}$ & Luminal B (Her-2 Negative) \\
\hline & BrCU 173 & Female & 43 & Infiltrating ductal carcinoma & $2 \mathrm{~A}$ & - \\
\hline & BrCU 174 & Female & 60 & Ductal carcinoma in situ & $1 \mathrm{~A}$ & Luminal B (Her-2 Positive) \\
\hline & BrCU 175 & Female & 53 & Ductal carcinoma in situ & 0 & Her-2 Positive \\
\hline & BrCU 176 & Female & 56 & Invasive ductal carcinoma & 4 & Luminal B (Her-2 Positive) \\
\hline & BrCU 177 & Female & 45 & Invasive ductal carcinoma & $2 \mathrm{~A}$ & Luminal B (Her-2 Positive) \\
\hline & BrCU 178 & Female & 39 & Invasive ductal carcinoma & $2 \mathrm{~A}$ & Luminal B (Her-2 Positive) \\
\hline & BrCU 179 & Female & 48 & Invasive ductal carcinoma & $3 B$ & Triple Negative \\
\hline & BrCU 180 & Female & 42 & Invasive ductal carcinoma and DCIS & $2 B$ & Triple Negative \\
\hline & BrCU 181 & Female & 45 & Invasive ductal carcinoma & $2 \mathrm{~A}$ & Her-2 Positive \\
\hline & BrCU 182 & Female & 71 & Invasive ductal carcinoma & $3 B$ & Her-2 Positive \\
\hline & BrCU 183 & Female & 49 & Invasive ductal carcinoma & $3 B$ & Luminal B (Her-2 Positive) \\
\hline & BrCU 184 & Female & 65 & Invasive lobular carcinoma & $2 \mathrm{~A}$ & Luminal A \\
\hline & BrCU 185 & Female & 38 & Ductal carcinoma in situ & 0 & Luminal A or B \\
\hline & BrCU 186 & Female & 62 & Fibroadenoma & $1 \mathrm{~A}$ & Luminal B (Her-2 Negative) \\
\hline & BrCU 187 & Female & 26 & Invasive ductal carcinoma and DCIS & $2 \mathrm{~A}$ & Luminal B (Her-2 Positive) \\
\hline & BrCU 188 & Female & 66 & Invasive ductal carcinoma & $3 \mathrm{~A}$ & Her-2 Positive \\
\hline & BrCU 189 & Female & 51 & Invasive ductal carcinoma & 4 & Luminal A or B \\
\hline & BrCU 190 & Female & 59 & Ductal carcinoma in situ & 0 & Luminal A or B \\
\hline & BrCU 191 & Female & 64 & Invasive ductal carcinoma & $2 \mathrm{~B}$ & Luminal B (Her-2 Positive) \\
\hline & BrCU 192 & Female & 46 & Invasive mammary carcinoma & 4 & Luminal B (Her-2 Positive) \\
\hline & BrCU 193 & Female & 60 & Invasive ductal carcinoma and DCIS & $1 \mathrm{~A}$ & Luminal B (Her-2 Positive) \\
\hline & BrCU 194 & Female & 48 & Invasive ductal carcinoma with extensive DCIS & 4 & Luminal A \\
\hline & BrCU 195 & Female & 52 & $\begin{array}{l}\text { Residual invasive ductal carcinoma and } \\
\text { intraductal carcinoma }\end{array}$ & $2 \mathrm{~A}$ & Luminal B (Her-2 Positive) \\
\hline & BrCU 196 & Female & 26 & Invasive ductal carcinoma with DCIS & $3 \mathrm{C}$ & Luminal B (Her-2 Negative) \\
\hline & BrCU 197 & Female & 32 & Infiltrating ductal carcinoma & $2 \mathrm{~B}$ & Luminal B (Her-2 Positive) \\
\hline & BrCU 198 & Female & 34 & Invasive ductal carcinoma & $2 \mathrm{~A}$ & Luminal B (Her-2 Negative) \\
\hline & BrCU 199 & Female & 58 & Invasive papillary carcinoma & $1 \mathrm{~A}$ & Luminal B (Her-2 Positive) \\
\hline & BrCU 200 & Female & 65 & 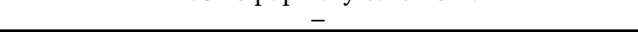 & $1 \mathrm{~A}$ & 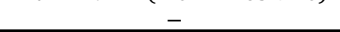 \\
\hline
\end{tabular}


Table S2 Primer sequences, annealing temperatures and PCR product sizes of all 6 methylated CpG sites in 3 genes.

\begin{tabular}{|c|c|c|c|c|c|}
\hline Gene & CpG sites & Primer & Primer sequence $\left(5^{\prime}-3^{\prime}\right)$ & $\begin{array}{l}\text { Annealing } \\
\text { temp. }\left({ }^{\circ} \mathrm{C}\right)\end{array}$ & $\begin{array}{l}\text { Product } \\
\text { size (bp) }\end{array}$ \\
\hline \multirow[t]{8}{*}{ NINL } & \multirow[t]{4}{*}{$\operatorname{cg} 09088834$} & methylated & Forward: GGGTATTAGTATTTAGGTACGATC & \multirow[t]{2}{*}{53} & \multirow[t]{2}{*}{65} \\
\hline & & & Reward: ACCATATAAAAATCTCTAATCGCG & & \\
\hline & & unmethylated & Forward: ATGGGGTATTAGTATTTAGGTATGATT & \multirow[t]{2}{*}{53} & \multirow[t]{2}{*}{71} \\
\hline & & & Reward: CACACCATATAAAAATCTCTAATCACA & & \\
\hline & \multirow[t]{4}{*}{$\operatorname{cg} 17729667$} & methylated & Forward: CGGTTTTCGTAAATTTTAGGGC & \multirow[t]{2}{*}{58} & \multirow[t]{2}{*}{86} \\
\hline & & & Reward: ACTCCGACAAAAACCAACG & & \\
\hline & & unmethylated & Forward: AAGGTGGTTTTTGTAAATTTTAGGGT & \multirow[t]{2}{*}{58} & \multirow[t]{2}{*}{94} \\
\hline & & & Reward: CAAAACTCCAACAAAAACCAACA & & \\
\hline \multirow[t]{8}{*}{ GPR39 } & \multirow[t]{4}{*}{$\operatorname{cg} 07785936$} & methylated & Forward: GTTTTTTTTTATGGTTTTATTTAGTTTTCC & \multirow[t]{2}{*}{58} & \multirow[t]{2}{*}{92} \\
\hline & & & Reward: AAATAACCACCTCAAACTCG & & \\
\hline & & unmethylated & Forward: GGTGTTTTTTTTTATGGTTTTATTTAGTTTTCT & 58 & 97 \\
\hline & & & Reward: CCAAATAACCACCTCAAАCTCA & & \\
\hline & \multirow[t]{4}{*}{$\operatorname{cg} 24659201$} & methylated & Forward: GGTCGATTTTTTGGAGTAGC & \multirow[t]{2}{*}{58} & \multirow[t]{2}{*}{56} \\
\hline & & & Reward: TACCAAAAACAACTAAACTCTACG & & \\
\hline & & unmethylated & Forward: GGGTTGATTTTTTGGAGTAGT & 58 & 62 \\
\hline & & & Reward: ATATTTACCAAAAACAACTAAACTCTACA & & \\
\hline \multirow[t]{8}{*}{ RHEB } & \multirow[t]{4}{*}{$\operatorname{cg} 03998173$} & methylated & Forward: CGTTAGTTTTGGTGTTCGTTTC & \multirow[t]{2}{*}{58} & \multirow[t]{2}{*}{62} \\
\hline & & & Reward: CGACGCTATTCCAAAAAATACG & & \\
\hline & & unmethylated & Forward: GTTTTGTTAGTTTTGGTGTTTGTTTT & 58 & 69 \\
\hline & & & Reward: CCCCAACACTATTCCAAAAAATACA & & \\
\hline & \multirow[t]{4}{*}{$\operatorname{cg} 21134096$} & methylated & Forward: GTCGAGTTAGTAGAGATTTCGTC & \multirow[t]{2}{*}{56} & \multirow[t]{2}{*}{51} \\
\hline & & & Reward: AACAAAATAAAAACGAATTCCCCG & & \\
\hline & & unmethylated & Forward: GTATTTGTTGAGTTAGTAGAGATTTTGTT & 56 & 61 \\
\hline & & & Reward: CCTAAACAAAATAAAAACAAATTCСССА & & \\
\hline
\end{tabular}

